\title{
QUANTITATIVE MODEL OF THE DECISION-MAKING PROCESS IN INTERNATIONAL BUSINESS DEALS
}

The proportion of emotionality and rationality in the decision-making process in international business deals is poorly researched field from the side of Economic Psychology. No matter this, from a scientific point of view it will be very useful to provide a model which is capable to define the amount of emotionality versus rationality. The difficulty in creating such a model arises from the fact that the elements in the decision-making process have a qualitative character. Therefore, it is important to propose a concept of a model which converts qualitative factors into quantitative indicators in order to define their ratio. This would allow a comparison between the two elements concerning emotional and rational behaviour, which are mutually an integral part of the decision-making process.

The article develops an approach that defines the share of emotionality to rationality in international trade deals. This approach is built up on different psychological meaning embedded in the questions of the survey. The degree of rationality and emotionality is determined on the basis of the answers that respondents give and depends on whether they choose answers that carry an emotional or rational charge. As the participants in the study are international counterparties from Europe, an analysis of their behavior towards the nationality of each of them is made. The uniqueness of intercultural differences also influences how rationally and emotionally the research results are distributed.

New features and trends in the development of international economic relations have a significant impact on the effect of rationality in the decision-making process, but the emotional component will continue to be a significant factor until the creation of Artificial intelligence to replace the human factor.

Keywords: economic behaviour, decision-making process, emotionality, rationality, international business deals.

There is a fundamental difference in the understanding of rationality of economists and psychologists. Classical economic theories support the idea that people choose rationally, while psychologists believe that the process of choice is accompanied and influenced by various internal and external psychological factors. Meanwhile, modern economists understand that none of these extremes is realistic [1]. Actually, falling into such categorical extremes is of no use to any science. In every economic decision there is a relationship between rationality and emotionality. The study of the proportional relationship between the two elements is of scientific importance, as it could be a response to interdisciplinary disputes.

The article is based on the cognitive approach in psychology [2], as the main purpose is to prove the thesis: In the international business deals the decisions represent a relationship between the elements of rationality and emotionality and are influenced by both the cognitive individual experience and the momentary psychological stimuli provided. This thesis is a mix of the concept of the unconscious in the

(C) Tileva I.G., 2021

Ivet G. Tileva - Doctor, Department of International Economic Relations and Business, University of National and World Economy, email: itileva@unwe.bg. 
psychology [3] [4] and understanding of behavioral economics [5]. In contrast to traditional economic understandings according to cognitive economics, people are not passive subjects who are influenced only by the external environment, but they are active participants who process information. [6] In this context, it is worth mentioning the term "collective unconscious", which contains all the minimal experience of humanity. The collective unconscious influences people's experiences and behavior even in the economy. [7] A major question for science is which of the two categories of factors (rationality and emotionality) dominates in the decision-making process in business deals, what is their proportional weight to the final decision and whether a person is able to control the choice by changing these factors.

It should be noted that many psychological factors such as fear, trust, honesty, greed, love, sense of responsibility and other manifestations of emotionality affect international trade. Undoubtedly, psychological factors may not be as important for national and international markets as value factors. To some extent, this is because psychological factors are more difficult to measure than quantitative ones. Their impact is not as clear as, for example, supply and demand on the market pricing mechanism. However, when, in one form or another, psychological factors relate to national economic reality and to international economic relations, they acquire economic significance and dimension. [8]

Theoretically international trade is a form of international economic relations [9]. As the subject of analysis is trade in marketing services, it is important to note that in recent decades the development trend of international trade in services is growing significantly [10].

Theoretical basis. Various scientists, economists and psychologists, are studying the decision making-process. Nobel Laureate in Economics Daniel Kahneman and his colleague the psychologist Amos Tversky have the main credit for the acceptance of Behavioral Economics, which is a major branch of Economic Psychology as equivalent to traditional economics. The main idea in their Prospect Theory is related to propensity to risk and the problem of loss and gain [11]. The theory claims that the economic choice is predetermined on the one hand by the pursuit of profit and on the other by the fear of loss.

There are two general elements in the Prospect Theory. First of them is connected with taking decision under risk. Decision-making under risk is based on heuristic methods, and the main influence on the choice is not the final possible result, but the idea of potential profit or loss. The theory proves by example that no matter how great the mathematical chance of winning is, people are more likely to prefer a smaller but secure profit. The idea of loss aversion is dictated by the bad emotions it brings - much worse and memorable than the positive emotions which the gain creates. So logically the fear of loss is a dominant factor in the economic decisions.

The second important element in the Prospect Theory is the Framing Effect. The way the information is presented is essential and can manipulate the choice in a 
certain direction [12]. The Framing Effect can seriously affect the rationality of the choice [13]. Framing of information in a particular way often turns out to be among the most provoking factors in the decision-making process [14] and it is a tool that can undoubtedly manipulate the relative attractiveness of the alternative. This is with a great significance in the context of international business deals, because most of them are negotiated by telecommunication means and concerns non-verbal communication.

Another theory that could be related to the decision-making process in the international business, is the Nudge Theory of Richard Thaler [15]. Despite "nudging" gained public popularity, it is more correct to use a scientific term such as "impulsing". Impulsing as a notion carries the meaning of deliberately creating a neural stimulus that elicits a reaction. This reaction, in turn, is expressed in the performance of a certain action. Impulse is a way of imposing a desire on the individual and inciting him to a specific act.

A basic postulate in the Nudge Theory is the idea of choice architecture. Anyone with the responsibility to create a context with conditions in which people make decisions is defined as an "architect of choice." The architect of choice aims to present the various alternatives. It is important to note that through manipulation, the person who selects may be inclined to prefer one option over another. Consciously or not, everyone can be in the position of "architect of choice" - from ordinary people to traders, doctors and other professionals.

Manipulation in the international business deals is a part of the decisionmaking process. It is important to notice that the use of term manipulation is often associated only with the negative side of the notion. The meaning of the concept is related to the urge to perform a specific action without the person being aware of paternalism, as it is hidden. Manipulation can lead to positive or negative consequences and depends entirely on the ethics of the user.

Although the concept of nudge concerns the manipulation of the decisionmaking process of an ordinary person, the theory can be related to business decisions in international trade. From an economic point of view, the theory contributes by asking a key question related to increasing the trade turnover of companies according to the goals of the trader. Every trader uses choice architecture, whether selling goods or services. In international trade deals, there are two situations in the use of Nudge theory. In the first case, both parties strive entirely and only for price dominance and own benefit. This situation implies non-potentiality and short-term business relationships. In the second type of situation, the supplier of the product does not necessarily strive for a higher profit margin, but for mutual benefit for both parties and society as a whole. This approach may not seem so effective at first glance, but in fact it is a long-term investment in a business partnership. Often, over time, a mutually beneficial approach proves to be much more sustainable and profitable. This type of partnership usually lasts longer and comes much closer to Richard Thaler's nudging concept. 
Experimental Design. In order to analyze the decision-making process in international business deals, the model in the article is a new concept of the author, which transforms the qualitative factors into quantitative ones. The limitations of the experiment are derived by the difficulty of gathering reliable information. The data tested is collected by a survey which precise modeling is very important for the experiment and the subsequent analysis. The model is designed within the limits of the data from the conducted survey, but could be adapted to any economic sector.

For the objective of the study, a survey is conducted. It includes three companies: Kourasanit Greece [16], Katy Paty [17] and Reed Exhibition Italia [18] in connection with their choice to use marketing products provided by the Bulgarian company The City Media Group (Градът Медиа Груп) [19]. The nationalities of the companies are respectively: Greek, Czech and Italian. The surveyed companies are with different nationalities and operate in the field of construction. The City Media Group provides opportunities for marketing positioning on various platforms. These 3 companies are chosen as a sample because they are connected with authors personal business experience, so the respondents are considered as reliable and answering by conscience.

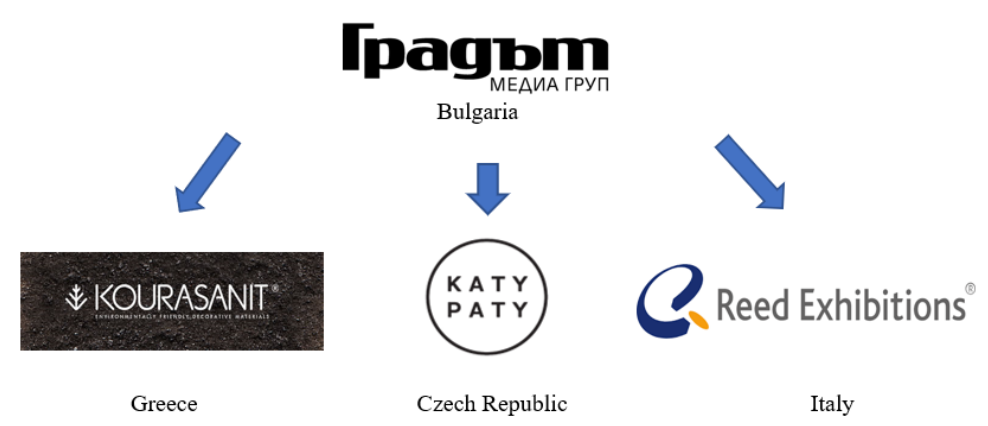

Fig. Surveyed counterparties

The sampling methodology of the three companies has several aspects that have been taken into account. First of all, the common between the three companies is that their activity is in the construction sector and are selected by international criterion. The communication is carried out directly through the headquarters of the parent company abroad. Second, since the focus of the experiment is on the nonverbal communication, the selected client companies of the media are ones that conducted the correspondence of the transaction mainly in written form and in a foreign language (English). Third, in order to diversify and make the survey more representative, the companies are selected according to different geographical regions of Europe, namely the south-eastern, central and Apennine regions.

The questionnaire aims to present the weight of rational and emotional factors. The article offers the idea that emotional factors have a hidden influence on the final decision. Hidden emotionality is often confused with rationality in the business be- 
havior because various factors influence on an unconscious level. At first glance, it seems that people make a rational choice, but in fact it is emotional. When respondents point to elements such as good service as an important component of the business; sympathy, reliability and security in the person being worked with; receiving bonuses and preferences; personal attitude; similar mentality and culture, in fact they show hidden emotionality in the deal. Emotional actions are often equated to irrationality. In general "irrational" could mean something emotional, but irrational is not equivalent to emotional. Some emotional actions can be defined as irrational, but also irrationality have a meaning of something religious, metaphysical, inexplicable and even occult.

At the same time, the idea for possibile hidden rationality in some seemingly emotional decisions should not be underestimated. There may be hidden rationality in some choices, even though people initially think of it as a manifestation of emotionality. The following example can be given. Nowadays, it is very fashionable to buy shares for Saint Valentine's day as a gift. The key point is that the shares chosen are not just a financial instrument for storing value. They are usually shares of a large company to which our partner has personal a attitude: flowers, underwear or chocolate, for example. Such a purchase can initially be interpreted as a manifestation of emotionality, but in practice there is a hidden rationality in it, too.

The idea of hidden emotionality is based on the concept of Emotional Finance [20] - another branch of Economic Psychology. Bothin the financial markets and in commercial deals, hidden emotionality can manifest itself. Of course, in the two processes it is radically different. On the financial markets there are similarities between the stock market bids and the gambling. Many people do play, not to increase their wealth or to gain profits, but to receive adrenaline and to feel pleasure. This act is not always generating positive feelings, but in general the individuals do not realise that these emotions are the reason to decide to play and lose, which is inexplicable from an economic point of view. Such hidden emotions could manifest in the trade deals. They are different because the decision-making process is connected with communication with a person. People can manipulate the final decision and provoke different types of feelings. The final choice could be unconsciously based on sympathy, trust, sense of prestige, maintaining social connections, etc.

For the aim of the survey, the questionnaire includes questions that take into account the weight of rational and emotional factors reflecting on the final decision. The survey contains questions related to the hidden emotionality of people, which is underestimated in the business relationships. The aim is, after processing the survey, to come up with conclusions about the proportionality of the factors and their dominance.

The questions from the questionnaire are addressed to foreign business clients and are divided into two main stages, through which the decision-making process in international trade deals passes. The first stage is related to the choice of a foreign market, and the second - with the choice of a particular supplier company. Not always the decision-making process necessarily passes in the sequence of firstly 
choosing a market and secondly choosing a company. In certain cases, choosing a company may precede the choice on a foreign market. In such circumstances, the market situation of the country in which the selected supplier company is based is a factor influencing the final decision. Indicators like political and economic stability, market potential, cultural and religious differences, social situation, etc. are taken into account. At the same time, choosing a supplier is influenced by the image of the company, the quality-price ratio in the product range, reliability and professionalism of the employees, etc. The sum of all subpoints of each question must be a 100 .

Survey design. Regardless of the sequence of choosing - firstly a market or a supplier company, the final decisions are influenced in a certain proportion by factors with rational and emotional nature. In this regard, the methodology of the survey is based on three components. The first component represents the proportional relationship between "emotionality" and "rationality" in an already completed business deal. This component includes 2 questions, each with 5 alternative subpoints, including one open option. One of the questions shows the orientation in choosing a foreign market, and the other - the orientation in choosing an international company:

Choosing an international market, rational orientation is related to answers such as: availability of market potential; stable political environment; lower purchase costs. Emotional orientation is determined by the choice of factors such as: cultural and religious similarities; similar mentality.

Choosing a company, rational orientation is expressed through the motives: perspective of the partnership; good product ratio between price and quality. Emotional orientation in choosing a supplier company shows the answers related to: confidence and sympathy for the person you work with; personal preferences such as better prices and bonuses; good personal attitude and quality of service from the person who manages the deal.

The questionnaire provides an open opportunity to fill in an important factor, which for one reason or another, does not appear in the questionnaire

The second component is related to the distinction of a leading factor with the greatest weight in choosing respectively an international market and an international company. The second component consists of two questions, each with 5 alternatives with subpoints, equivalent to the subpoints in the first component of the questionnaire. The second component includes an open possibility for answering. The third component has a prognostic purpose and it is linked to the future intentions of the buying counterparty to continue the business relationship. This component should show the main reason for the choice. The component includes one question, and the answer options are based on the alternative subpoints of the questions from the first component.

It is important to specify the communication history between the Bulgarian specialist who concludes the deals and the three surveyed counterparties. The three foreign companies for first time negotiated a deal with The City Media Group. The 
information related to the initial contact with the surveyed companies is useful for the research, as it happens individually and in a radically different way. The first contact of the City Media Group with the Greek company was established due to a recommendation from a Bulgarian partner of Kourasanit. The second contact with the company Katy Paty was initiated by the Czech company. The third contact with Reed Exhibitions is an initiative of an employee of the City Media Group. The initial contact with the Italian company was preceded by a previous working relationship between the employee of the City Media Group and another Bulgarian company.

Survey results. After the questionnaire is sent to the three chosen companies, the processed data is presented in four tables. The analysis of the results goes through 5 stages, which have the following objectives:

- deriving a proportional dependence in choosing a foreign market;

- deriving proportional dependence in choosing an international company;

- calculation of an average value between the answers related to the choice of market and supplier company;

- establishing the proportionality between the main factors in choosing respectively a foreign market and a supplier company;

- establishing the proportionality between the dominant factors influencing the re-conclusion of the deal.

It is important to note that it is hard to take into account the factor of hidden emotionality due to its unconscious nature. In some cases, it may be predominant, but logically almost unprovable.

Table 1

Selection of a foreign market: ratio of the influencing factors

\begin{tabular}{|c|c|c|c|}
\hline Company & Emotionality & Rationality & Ratio \\
\hline Kourasanit & $25 \%$ & $75 \%$ & 0,33 \\
\hline Katy Paty & $30 \%$ & $70 \%$ & 0,43 \\
\hline Reed Exhibitions & $20 \%$ & $80 \%$ & 0,25 \\
\hline
\end{tabular}

Table 1 presents the overall results of the three companies' survey, showing a proportional relationship between the responses. The ratio between emotionality and rationality is in favor of rationality and the coefficient varies in the range of 0.25 and 0.43. Choosing a foreign market, respondents show greater rationality. Emotionality has an average influence on the final choice of a foreign market in the amount of 1/4.

Table 2 repeats the methodology from Table 1, but in this case the subject of analysis is the choice of particular company. In this context, there is some difference in the proportions from Table 1. It is noteworthy that emotionality has a significantly greater impact on the choice of supplier company than on the choice of a foreign market. In this case, the action of emotional factors represents on average about $1 / 3$ of choosing foreign supplier company. The average value obtained from the propor- 
tional ratio between the sum of all emotional and rational factors in the survey is 0.76 , respectively, and it is in favor of rationality. Therefore, in the context of the research it can be concluded that about $24 \%$ of the final decision to conclude an international trade deal is in favor of emotionality.

Table 2

Selection of a foreign supplier company: ratio of the influencing factors

\begin{tabular}{|c|c|c|c|}
\hline Company & Emotionality & Rationality & Ratio \\
\hline Kourasanit & $85 \%$ & $15 \%$ & 5,67 \\
\hline Katy Paty & $50 \%$ & $50 \%$ & 1 \\
\hline Reed Exhibitions & $50 \%$ & $50 \%$ & 1 \\
\hline
\end{tabular}

The next questions from the survey are related to challenges and potential for development of intercompany relations. Independently from the number of new sales, the key issue for each company is the establishment of long-term business relationships. An important point in the realization of a commercial deal is its repeatability. It is usually associated with greater security for companies. In addition, working with already known and reliable business partners often provides preferential terms and takes less operational resources of employees. The analysis of the proportional dependence between rationality and emotionality proves the presence of emotionality in the final business decisions and in the intention to repeat the deal. The survey contains information for the main factors which determine the choice. The results of the study, related to the choice for realization a deal already made, show that hidden emotionality influences the final business decisions.

Table 3

A main factor for selecting a particular foreign market and supplier company

\begin{tabular}{|c|c|c|}
\hline Company & Market selection & Company selection \\
\hline Kourasanit & rational & Emotional \\
\hline Katy Paty & rational & Emotional \\
\hline Reed Exhibitions & rational & Rational \\
\hline
\end{tabular}

Table 3 is based on a question with only one alternative answer. The purpose of the question is to provide information for the most important factor influencing the choice of a foreign market and an international supplier company, respectively. When respondents have only one alternative answer, it is clear that in choosing a foreign market $100 \%$ of the decision is based on rationality. Things are completely different in the context of choosing a supplier company. In this case, rationality has only $1 / 3$ significance compared to emotionality. According to the research, the factors based on emotionality have their influence on the final decision of the three companies and should definitely not be overlooked. 
As already mentioned, every business is interested in maintaining long-term relationships with loyal partners. In this regard, it is important to consider the characteristics of the factors which influence the repetition of the choice, in particular - the influencing factors for re-conclusion of a deal with the company that supplies the product. For this purpose, the questionnaire has one question related to the most important dominant factor which would predetermine a repetition of the deal. The function of the question is to present the first and most important factor that is most significant in the mind of the business client. This factor may indicate rationality or emotionality (the so-called hidden emotionality).

Table 4

Selection of a dominant factor influencing the re-conclusion of the deal

\begin{tabular}{|c|c|}
\hline Company & Main dominant factor \\
\hline Kourasanit & rational \\
\hline Katy Paty & emotional \\
\hline Reed Exhibitions & rational \\
\hline
\end{tabular}

Table 4 presents the answers of the three respondents, which are related to the possible continuation of the business relationships with the Bulgarian company. When it comes to future relationships, rationality prevails in the choice. Similar to the results related to already realized deals, in $1 / 3$ of the responces emotional factors are with dominant importance for continuing the partnership with the particular company.

Analysis of the behavior of counterparties according to nationality. Of course, there are characteristics related to nationality that could theoretically be related with the business behavior of the respondents in the context of international trade deals. Companies from three different nationalities are included in the survey. The final decision is made and announced by a specialist in the company, whose nationality corresponds to the nationality of the organization. Based on the results in Table 3 , it can be concluded that the Greek, Czech and Italian counterparties demonstrate the same rational behavior when it comes to selecting a specific market. Things are not the same when it comes to choosing a particular company. In this case, only the Italian counterpart shows rationalism, while the Czech and Greek give the impression of selection on the base of the so-called hidden emotionality.

The study takes into account one of the most important elements of a commercial deal, namely the possibility of its repetition over time. Based on the data from Table 4, the following conclusion can be made. Concerning two of the counterparties (the Greek and the Italian), the dominant factor for the repetition of the trade deal is rationality. The Czech counterparty demonstrates a "hidden emotionality" in choosing the dominant factor for the repetition of the deal. In the context of the survey, it should be noted that counterparties from Central and Eastern Europe are more likely to show hidden emotionality in trade deals than counterparties from the Apennine part of Europe. 
As a factor determining the difference in the behavior of the Italian counterparty could be accounted the geographical proximity to the Western European countries with which the country trades regularly: Germany, Austria, Switzerland and France. Only two of the countries with which Italy borders are Central European, which is a prerequisite for the increased influence of Western countries. This inevitably has an impact on the business communication and behavior of the Italian counterparty. This inevitably has an impact on the business communication and behavior of the Italian counterparty. The Greek counterparty shows a higher rationality in the market selection, but the behavior in choosing the Bulgarian company can be defined more as emotional. This behavior can be largely explained by cultural interaction based on constant exchange of people between the two countries with the main purpose of work and tourism. On the other hand, the Czech Republic also borders with Western European countries, such as Germany and Austria, but also with Central European countries - Poland and Slovenia. The influence of border countries on the Czech Republic can be defined as dual. However, in the context of the survey, the Czech counterparty reported the most emotional behavior of the three surveyed companies. In view of the findings made for the other two counterparties in the study, the behavior of the Czech counterparty can be classified as uncharacteristic. It can be assumed that this phenomenon is due to unconscious mental processes on the part of the individual who makes the final decision. These processes are usually related to past experiences on which the concept of associative thinking is built. It could be focused on certain elements of the deal that affect the final decision. Such associations are possible to be related with: the Bulgarian country, the particular company with which the deal is concluded, with elements of the logo, name or overall corporate image of the supply company.

\section{Conclusion}

At the end of the analysis, several basic conclusions can be made. Undoubtedly, rationality in business has a more serious role in the decision-making process than emotionality. Besides, hidden emotionality is harder to identify. However, the results of the presented example show that emotional factors in business should not be underestimated or denied. In this regard, the emotionality in international deals at first glance can not always be assessed as such, because it is hidden behind understandings of rational behavior. It is no coincidence that when choosing a particular supplier, the importance of emotion is greater. This is predetermined by the fact that the person who takes the decision has a larger set of specific information that can be synthesized more easily. In addition, the choice of company involves the human factor that mediates communication. Regardless of the influence of many factors, the human factor is the main and predetermining conclusion of a deal or vice versa - it can negatively affect the choice of a potential business partner.

The survey of the proportionality between "emotionality" and "rationality" in international business deals has the potential to be extremely beneficial for companies. With proper company analysis, each economic unit could collect and process information about its international customers. As a result, individual companies will 
have the opportunity to influence business processes by managing the factors related with choice. As a recommendation, in order to make more synthesized and general conclusions about the decision-making process in international trade, it is recommendable the scope of the survey to be expanded with different sectors of the economy.

\section{References}

1. Lewis A., Webley P., Furnhman A. The new economic mind: The social psychology of economic behaviour. 2nd ed., Harvester Wheatsheaf, 1995, 332 p.

2. Martin D. Psychology of human behavior. The Teaching Company, 2006.

3. Freud S. Psychologie des Unbewußten (Bulg. ed.: Froid Z. Psikhologiia na nes"znavanoto. Sofiia, Kolibri, 2014, 288 p.).

4. Freud S. Vorlesungen zur Einführung in die Psychoanalyse (Bulg. ed.: Froid Z. Lektsii za v"vedenie v psikhoanalizata. Sofiia, Kolibri, 2013, 472 p.).

5. Watson J. Psychology as the behaviorist views it. Psychological Review, American Psychological Association, 1913, no. 20, pp. 158-177.

6. Sternberg R. Cognitive psychology (Bulg. ed.: St"rnb"rg R. Kognitivna psikhologiia. Sofiia, Iztok-Zapad, 2012, 624 p.).

7. Jung C.G. Die Archetypen und das kollektive Unbewusste (Bulg. ed.: Iung K. Arkhetipovete i kolektivnoto nes"znavano. Sofiia, Lege Artis, 2016. 376 p.)

8. Danov D. Psikhologicheski faktori v MIO [Psychological factors in International Economic Relations]. Sofiia, Stopanstvo, 2002, 87 p.

9. Zhelev P. Teoriia na MIO [Theory of International Economic Relations]. Sofiia, Stopanstvo, 2015, 225 p.

10. Danov D. Tendentsii v mezhdunarodnite ikonomicheski otnosheniia [Trends in international economic relations]. Sofiia, Stopanstvo, 2001, $225 \mathrm{p}$.

11. Kahneman D., Tversky A. Prospect theory: An analysis of decision under risk. Econometrica, 1979, no. 47(2), pp. 263-291.

12. Tversky A., D. Kahneman. The framing of decisions and the psychology of choice. Science, 1981, no. 211, pp. 453-458.

13. Tversky A., D. Kahneman. Rational choice and the framing of decisions. Journal of Business, 1986, no. 59, pp. 251-278.

14. Thomas K., Millar R. Reducing the framing effect in older and younger adults by encouraging analytic processing. The Journals of Gerontology Series B: Psychological Sciences and Social Sciences, 2011, no. 67B (2), pp. 139-49.

15. Thaler R., Sunstein C. Nudge: Improving decisions about health, wealth, and happiness. Yale University Press, 2008, 293 p.

16. Official website of Kourasanit Greece. Available at: http://www.kourasanit.com/en (accessed 15.11.2020). 
17. Official website of Katy Paty. Available at: https://www.katypaty.com (accessed 15.11.2020)

18. Official website of Reed Exhibitions Italia. Available at: https://www.reedexhibitions.com/ (accessed 15.11.2020)

19. Official website of The City Media Group. Available at: https://www.gradat.media/ (accessed 15.11.2020)

20. Tuckett D. Minding the markets: An emotional finance view of financial instability. Palgrave Macmillan, 2011, 232 p.

Оригинальность $94 \%$

Получено 02.12.2020 Принято 28.12.2020 Опубликовано 30.06.2021

\title{
И.Г. Тилева
}

\section{КОЛИЧЕСТВЕННАЯ МОДЕЛЬ ПРОЦЕССА ПРИНЯТИЯ РЕШЕНИЙ В МЕЖДУНАРОДНЫХ ТОРГОВЫХ ОПЕРАЦИЯХ}

\begin{abstract}
Соотношение эмоционального и рационального в процессе принятия решений в международных деловых операциях - малоизученная область экономической психологии. Однако с научной точки зрения было бы очень полезно создать модель, которая сможет определять уровень эмоциональности по сравнению с рациональностью. Трудности создания такой модели связаны с тем, что факторы в процессе принятия решений имеют качественный характер. Поэтому необходимо приобрести концепцию модели, которая конвертирует качественные фракторы в количественные показатели с целью определения их соотношения. Это позволило бы сравнивать эти два элемента, которые относятся к эмоциональному и рациональному поведению и оба являются неотъемлемой частью процесса принятия решений.

В статье рассматривается способ, определяющий долю эмоциональности и рациональности в международных коммерческих операциях. В основе этого способа находится особый психологический смысл вопросов анкеты. Уровень рациональности и эмоциональности определяется согласно сущности ответов респондентов и зависит от того, выбирают ли они ответы, несущие эмоциональный или рациональный компонент. Поскольку участники исследования являются международными контрагентами из Европы, проводится анализ их поведения по отношению к национальности каждого из них. Своеобразие межкультурных различий тоже оказывает влияние на то, как рациональное и эмоциональное распределяются в результатах исследования.

Новые особенности и тенденции в развитии международных экономических отношений оказывают существенное влияние на эффект рациональности в процессе принятия решений, но эмоциональная составляющая будет продолжать оставаться значимым фактором до тех пор, пока не будет создан Искусственный интеллект, который заменит человека.

Ключевые слова: экономическое поведение, прочесс принятия решений, эмоциональность, рациональность, международные бизнес операции.
\end{abstract}

Ивет Г. Тилева - канд. экон. наук, кафедра международных экономических отношений и бизнеса, Университет национальной и мировой экономики, e-mail: itileva@unwe.bg.

Received 02.12.2020 Accepted 28.12.2020 Published 30.06.2021 